\title{
Origen y evolución arquitectónica de los conventos cordobeses de Madres Dominicas
}

\author{
Origin and architectural evolution of the Cordovan convents of \\ Dominican Mothers
}

Francisco Manuel CARMONA CARMONA

Universidad de Córdoba

Recibido: $12 / \mathrm{IV} / 2018$

Aceptado: 8/VI/2018

RESUMEN: A partir del análisis de la abundante información inédita que nos ofrecen tanto archivos como fondos con documentación conventual, en esta investigación hemos intentado destacar las distintas vías de origen y evolución arquitectónica de los claustros cordobeses de dominicas. Si tradicionalmente se ha venido vinculando únicamente la actividad fundadora y constructiva a determinadas clases privilegiadas, este estudio deja patente que el impulso de la comunidad femenina en las estructuras edilicias que permiten su reunión ha quedado olvidado o silenciado. Así, nos proponemos el triple objetivo de evidenciar el desconocimiento sobre las vías de origen, formación, desarrollo y defensa de las edificaciones conventuales; ponderar la importancia del impulso femenino para con ello, así como destacar el potencial de la documentación conventual para la Historia del Arte.

Palabras clave: Conventos de clausura; Iglesia conventual; Monasterio; Monjas; Celda; Defensa del patrimonio artístico.

ABSTRACT: From the analysis of the abundant unpublished information that both archives and funds offer with conventual documentation, in this investigation we have tried to highlight the different ways of origin and architectural evolution of the Dominican cloisters of Cordoba. If traditionally only founding and constructive activity has been linked to certain privileged classes, this study makes clear that the impulse of the female community in the building structures that allow its meeting has been forgotten or silenced. Thus, we propose the triple objective of evidencing ignorance about the routes of origin, formation, development and defense of convent buildings; ponder the importance of the feminine impulse to do so, as well as highlight the potential of the conventual documentation for the History of Art.

Keywords: Closing convents; Convent church; Monastery; Nuns cell; Defense of artistic heritage.

Afortunadamente, desde hace relativamente poco tiempo, los estudios específicos sobre el fenómeno conventual femenino de épocas pasadas se están enriqueciendo gracias a un amplio abanico de perspectivas, pues, con mayor o menor hincapié, revisan las interpretaciones que desde el prisma masculino se han realizado sobre la peculiar idiosincrasia de estos grupos de mujeres de vida consagrada. Pese al carácter parcial que supone tomar como muestra una única comunidad o un concreto marco espacio-temporal, estamos convencidos que es preciso ponderar su nivel de participación como innegable parte representativa en el horizonte de la vida regular femenina ${ }^{1}$.

\footnotetext{
1 Ya advertida su necesidad por Á. ATIENZA
} 
Si bien la atención historiográfica al fenómeno conventual femenino ha estado focalizada mayormente en su participación económica, social y cultural ${ }^{2}$, la atención a las vicisitudes que rodean a las obras artísticas que se atesoran en ellos necesita de un obligado estudio de síntesis; por cuanto la Historia del Arte se ha inclinado más hacia el patrimonio que destaca por su riqueza material, calidad técnica, renombre de su autoría u originalidad iconográfica. Rara vez, y solo en casos muy concretos, los contextos, vías de origen y desarrollo de las obras artísticas conventuales han sido objeto de estudio en su visión de conjunto ${ }^{3}$. En lo que a la arquitectura se refiere, sí se conoce ampliamen-

LÓPEZ, "El mundo de las monjas y de los claustros femeninos en la Edad Moderna. Perspectivas recientes y algunos retos", en E. SERRANO MARTÍN (coord.), De la Tierra al Cielo. Líneas recientes de investigación en Historia Moderna, Zaragoza, 2012, pp. 89-108. Previamente, esta autora acometió la impagable labor de síntesis del fenómeno conventual español en Tiempos de conventos. Una historia social de las fundaciones en la España Moderna, Madrid, 2008.

2 Para el caso cordobés resultan fundamentales los aportes de F. CERRATOS MATEOS, Monasterios femeninos de Córdoba: patrimonio, rentas y gestión económica a finales del Antiguo Régimen, Córdoba, 2000; M. M. GRAÑA CID, Religiosas y Ciudades. La espiritualidad femenina en la construcción sociopolítica urbana bajomedieval (Córdoba, siglos XIII-XVI), Córdoba, 2010; M. M. GRAÑA CID, "Poder nobiliario y monacato femenino en el tránsito a la Edad Moderna (Córdoba, 14951550)", Cuadernos de Historia Moderna, Vol. 37, 2012, pp. 43-72; S. GÓMEZ NAVARRO, "Patrimonio monástico y conventual en la España Moderna: formas y fuentes de formación y consolidación", en M. I. VIFORCOS MARINAS y R. LORETO LÓPEZ (coords.), Historias compartidas, religiosidad y reclusión femenina en España, Portugal y América, siglos XVI-XIX, León, 2007, pp. 435465; Y. V. OLMEDO SÁNCHEZ, "Bastiones de oración: arquitectura y espacios monacales femeninos en el Reino de Córdoba durante la Edad Moderna", Tiempos Modernos, no 25, 2012, p. 40.

${ }^{3}$ Se acerca a este propósito de ofrecer una visión general del conventualismo de la capital cordobesa J. DOBADO FERNÁNDEZ y M. YLLESCAS ORTÍZ, Córdoba ciudad conventual, Córdoba, 2014; mientras que de la muestra conventual dominica que nos ocupamos, únicamente A. VILLAR MOVELLÁN (dir.), El Convento de Dominicas del Corpus Christi de Córdoba. 1609-1992, Córdoba, 1997. te el ímpetu fundacional y su dotación por parte de las clases privilegiadas; no obstante, hemos de desconfiar que todo el patrimonio arquitectónico conformado por las comunidades enclaustradas haya surgido únicamente de la pecunia de ellas, quedando olvidado o silenciado el impulso y la iniciativa comunitaria o individual de las integrantes del claustro. Es obligado, por tanto, adentrarnos en la intrahistoria conventual a través de determinados comportamientos grupales y aspectos de la vida privada de aquellas mujeres que en su gran mayoría no optaron libremente por la vida consagrada, sino que fueron piezas sobre el damero del difícil arte de las estrategias familiares.

En este sentido, y al hilo de una investigación más profunda, nos proponemos a través de los conventos cordobeses de Madres Dominicas un triple objetivo: de un lado, evidenciar el desconocimiento sobre las vías de origen, formación, desarrollo y defensa de las estructuras edilicias que conforman estos claustros; de otro, delatar y valorizar la importancia que el impulso femenino ha tenido para con ello; y por último, destacar el interés y potencial de los archivos y fondos documentales de origen conventual para la Historia del Arte.

\section{POTENCIALIDAD DE LAS FUENTES}

Apoyamos nuestra investigación principalmente en la selección de informaciones inéditas procedentes de los distintos fondos documentales manejados ${ }^{4}$, de donde hemos

\footnotetext{
${ }^{4}$ Los archivos consultados y las abreviaturas utilizadas: Archivo Conventual de Madre de Dios de Baena (en adelante ACMDB); Archivo Ducado de Alba (en adelante ADA); Archivo Federación Nuestra Señora del Rosario (Bética) de MM. Dominicas. Córdoba (en adelante AFNSR); Archivo General Obispado de Córdoba-Sección Órdenes Religiosas Femeninas (en adelante AGOC); Archivo Histórico Nacional (en adelante AHN); Archivo Histórico Provincial de Córdoba (en adelante AHPCO); Archivo Histórico Palacio de Viana. Córdoba (en adelante AHPV). Nuestro sincero agradecimiento a todos los profesionales que prestan servicio en Archivos y Bibliotecas, por cuanto nunca es suficientemente reconocida su labor y suponen
} 
podido extraer los métodos y prácticas habituales en la génesis y evolución del patrimonio artístico de los conventos cordobeses de dominicas; y de la bibliografía especializada, su grado de participación en la fenomenología conventual española. En todo este proceso hemos comprobado cómo la casuística en las vías de formación artística es variada, imponiéndose un denominador común: la mujer. Por cuanto por, para y de ella surge todo el atesoramiento de obras de arte y la arquitectura que permite su reunión en comunidad. Aunque su destino haga suponer $a$ priori responde al fervor y devoción religiosa de la comunidad, las evidencias nos mostrarán el índice de participación de los distintos estamentos sociales implicados en el fenómeno conventual: de fundadores y patronos, de los bienhechores, de los familiares de las sores allí reunidas, y como no, del esfuerzo individual que ejercieron intramuros gran número de ellas.

Respecto del patrimonio inmueble se hace obligado diferenciar entre iglesia conventual y monasterio en el establecimiento de la capacidad fundadora, constructiva y dotacional. Por un lado, es conveniente acudir a los estatutos fundacionales y concordias para advertir que la iglesia conventual se estructura como eje principal de las inquietudes de patrocinio por parte de la nobleza y el alto clero. Para el resto de dependencias conventuales -a excepción del coro, donde comprobamos ejemplos que señalan idénticos intereses para la significación política del apellido fundador ${ }^{5}$ - el manejo de la documentación nos señala que se deja las más de las veces al albedrío de la comunidad y sufragio mediante los recursos que esta sea capaz de obtener y gestionar para

una inestimable ayuda a la investigación históricoartística; y muy especialmente a las comunidades de RR.MM. dominicas de Santa María de Gracia de Córdoba y Madre de Dios de Baena, quienes nos han permitido y facilitado la consulta de sus valiosísimos fondos documentales.

5 F. M. CARMONA CARMONA, "Parámetros nobiliarios y política de prestigio en el convento Madre de Dios de Baena (Córdoba)", Hispania Sacra [en prensa]. este fin, por lo que se hace necesaria esta diferenciación. No obstante, hemos de advertir que en las ampliaciones de los inmuebles cenobíticos participan más factores que la simple presión demográfica, por lo que hemos de atender a la calidad social de sus integrantes y evidenciar su peso específico. Así, la progresiva ampliación de los límites conventuales y la adaptación de estancias y dependencias van a estar condicionadas en gran medida de estas dos variables. Es aquí donde la casa-celda cobra un papel preponderante para la conformación definitiva del inmueble, llegando incluso a constituir una invariante tipológica.

También observamos cómo, gracias al ímpetu y sacrificio económico femenino, se acometen directamente del peculio personal de las religiosas numerosas obras de reparo y mantenimiento, una práctica generalizada en todos los conventos femeninos de cualquier orden, y gracias a las cuales hoy podemos contar con estas edificaciones monumentales. Otras veces, la iniciativa personal o comunitaria propicia que los considerados bienhechores sufraguen las reparaciones necesarias en el convento, unas rogativas que abundan en la correspondencia y memoriales conservados en los fondos documentales. La solicitud de dispensa para poder aplicar la dote de una recién profesa en obras de ampliación y reparación fue también una práctica frecuentemente utilizada, por la cual se sacrifica el rendimiento del capital dotal en pos del inmueble o sus reparos. Todos estos mecanismos entendemos que son merecedores de su justa ponderación y hace necesario evidenciar su importancia.

Sin embargo, rara vez hemos encontrado señaladas explícitamente en la documentación conventual la finalidad, autoría y precio del gasto en obras arquitectónicas. Para ello son fuente noticiosa de primer orden los libros de cuentas o gastos, quienes a veces aluden por sus nombres a los sacadores de piedra, porteadores, albañiles, herreros, carpinteros, plateros, entalladores y pintores contratados para las obras, los reparos y la adecuación de todos los espacios preceptua- 
dos por Trento. Si cabe, lo más interesante de estos libros es que se indican los escribanos públicos ante los que se obligaron a realizar tales obras y bienes, lo que facilita enormemente la labor del historiador del arte en el contraste de información. Pero estas noticias son rara avis en el grueso documental manejado.

\section{CAUCES DE FORMACIÓN DE LOS INMUEBLES CONVENTUALES}

En los diez conjuntos claustrales estudiados $^{6}$, asistimos a una disparidad de procesos fundacionales por los que se establecen determinadas peculiaridades en los mecanismos de conformación conventual y donde la iglesia actúa como eje aglutinador. Dependiendo de la motivación fundacional, y habida cuenta que ningún convento fue edificado ex profeso sino mediante la ocupación de casas para tal fin, observamos cómo la alta nobleza cordobesa y el alto clero fundador -emulados por hidalgos y magnates- establecen la necesidad de adecuar convenientemente la iglesia conventual como instrumento de su representación política y social, imponiendo cláusulas en los estatutos fundacionales para que en la capilla mayor se materialice la estratégica disposición de los blasones familiares, el enterramiento exclusivo del fundador y su linaje en lugar preeminente y se disponga de entrada y tribuna particular. Todo ello ha de servir como he-

\footnotetext{
${ }^{6}$ Los cinco conventos establecidos en la ciudad de la Mezquita, con las abreviaturas que desde ahora nos referiremos: Convento Corpus Christi de Córdoba (en adelante CCC); Convento Espíritu Santo de Córdoba (en adelante CES); Convento Jesús Crucificado de Córdoba (en adelante CJC); Convento Regina Coeli de Córdoba (en adelante CRC); Convento Santa María de Gracia de Córdoba (en adelante CSMG). Enclavados en villas cordobesas, y las abreviaturas con las que los conoceremos: Convento Jesús María de Scala Coeli de Castro del Río (en adelante CJMSC); Convento Madre de Dios de Baena (CMD); Convento Nuestra Señora de la Consolación de La Rambla (en adelante CNSC); Convento Santa Ana de Lucena (en adelante CSA); Convento San Martín y Llagas de Cristo de Cabra (en adelante CSMLL).
}

rramienta de diferenciación, a lo que ayuda también el ceremonial litúrgico establecido.

Del mismo modo, las capillas y altares laterales eran demandados por otras familias no tan poderosas y cuyo patrocinio se constata tanto en la documentación conventual como en la notarial a través del establecimiento de capellanías de índole escatológica, y a veces con posibilidad de enterramiento en la misma. Por ello se procedía a la consiguiente dotación de ajuar litúrgico y exorno del retablo por parte de estas familias, que comúnmente lo eran de religiosas allí congregadas.

Por su parte, el coro, ese espacio intermedio entre lo público y la clausura, se sitúa a los pies de la iglesia conventual y lo separa de esta una reja con cratícula. En los dos ejemplos que disponemos de conventos de fundación altonobiliaria se demuestra la utilización de este espacio en los mismos términos que la iglesia, pues sirve igualmente de instrumento de magnificencia y escaparate de poder del linaje que favoreció la reunión. (Fig. 1)

Otra cuestión bien distinta es la clausura, o resto de espacio conventual donde se desarrolla la vida en comunidad. Pese a establecerse en los estatutos fundacionales generalmente la dotación de inmuebles y recursos económicos para el mantenimiento de la misma, la documentación evidencia que esta asignación de renta únicamente favorece el mantenimiento de las sores fundadoras y aquellas que acceden al coro con derecho de presentación del patrono, por lo que la adecuación e incorporación de nuevos espacios irá en correspondencia con el aumento de población conventual ${ }^{7}$. Esta situación se

\footnotetext{
7 Por ejemplo la compra realizada en 1571 de unas casas anejas a la huerta del convento de Jesús Crucificado para ampliación del inmueble conventual, o la permuta de casas realizada en 1674 entre este mismo cenobio y la catedral cordobesa para poderlas incorporar a la clausura. AHPCO, Clero, Libro 23. CJC, Protocolo de la hacienda de 1765, fols. 4r y 400r. Gran parte de la conformación del solar conventual se documenta perfectamente en este libro.
} 


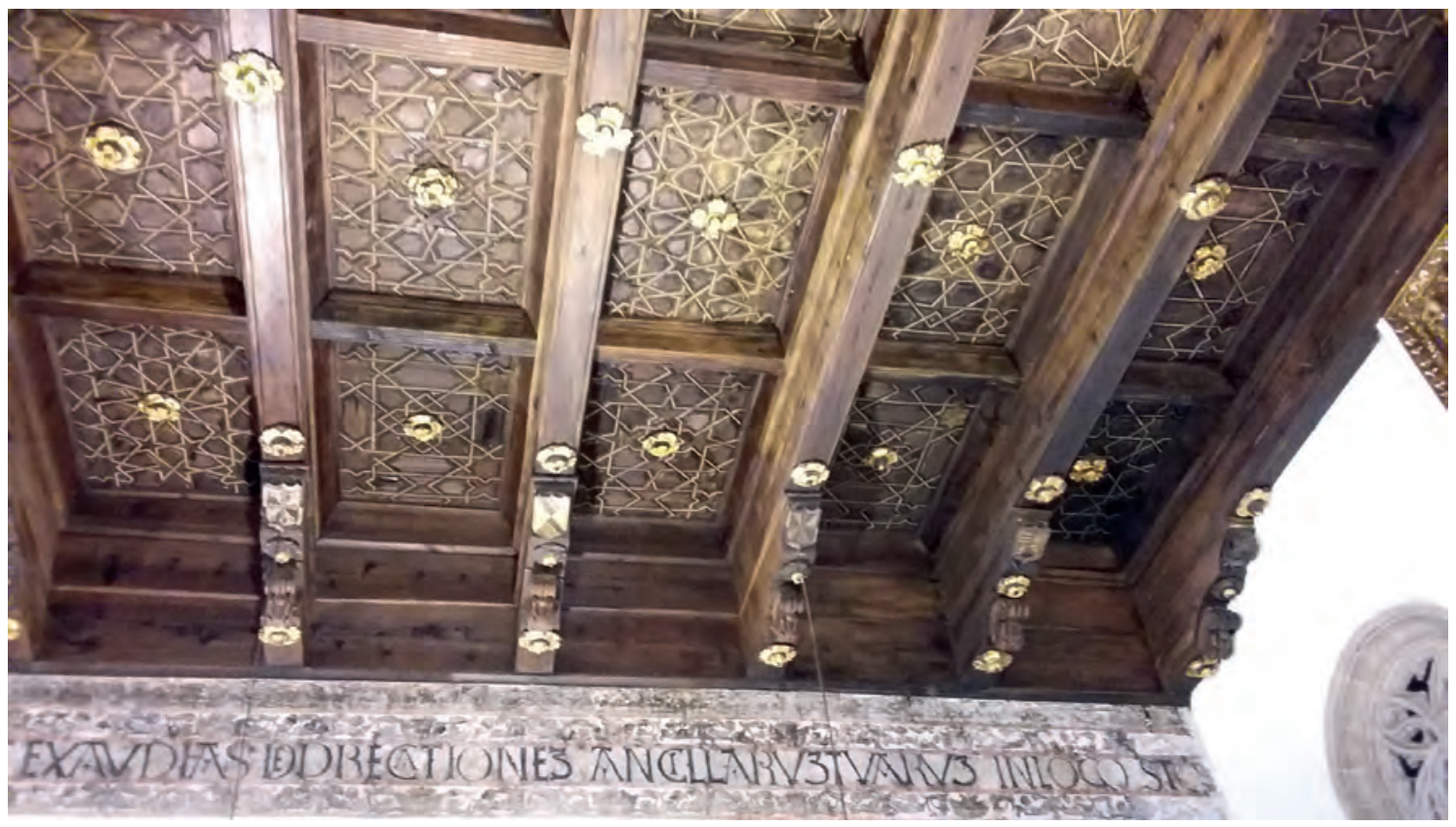

- Fig. 1. Alfarje del coro con armas del matrimonio fundador en sus ménsulas. Convento de Madre de Dios de Baena. Foto gentileza de la comunidad de RR.MM. dominicas de Madre de Dios de Baena.

palia mediante la incorporación sucesiva $\mathrm{y}$ la adaptación de casas vecinas o construyendo en el espacio destinado a huerto las casas llamadas celdas, por lo general sufragadas por las familias para facilitar el ingreso en el claustro de distintas sores del mismo linaje. Resulta significativa la incidencia que para la conformación del inmueble conventual -y por ende del urbanismo de la localidad- tiene la incorporación de esas casas aledañas en concepto de celdas, las que tras el tapiado de ventanas y puertas exteriores se unen a la clausura mediante la apertura de vanos en las medianerías. Un fenómeno del que participan la inmensa mayoría de conventos de monjas contemplativas de cualquier orden, tanto en España como en Latinoamérica, dado que como nos refiere Fernando Benítez:

“El convento constituyó en realidad una extraña ciudad privada de hombres, con sus callejones retorcidos donde se disponían caprichosamente las celdas. Contra lo que se cree, no eran cuartos dispuestos en los claustros, al modo de los conventos de frailes; los conventos de monjas donde no se guardaba una vida comunal rigurosa eran muy diferentes.
Se llamaba también 'celda' a una casa de dos pisos que tenía en la planta baja las habitaciones de las esclavas o las criadas, la cocina, su tina de baño -de azulejos o de barro-con sus braseros para calentar el agua, los lavaderos, tal vez un gallinero pequeño, un jardincillo y una bodega.

En la planta alta figuraban una o dos recámaras, una espaciosa antecámara y un mirador. Por supuesto, no faltaban las macetas ni las jaulas de los pájaros. Éstas eran las celdas de las monjas ricas que compraban y revestían de cuadros, bargueños o escribanías, sillones, alfombras, relojes, camas y objetos preciosos. [...] El monasterio proveía el pan, el carnero o el pescado y la monja se mandaba hacer su comida, sin obligación de acudir al refectorio.

No faltaban los claustros propiamente dichos. En el bajo funcionaba la gran cocina comunal, la capilla y la portería con uno o dos tornos a cargo de las madres torneras. [...] Figuraban también los almacenes, la ropería y la enfermería [...] En el claustro alto se disponían las celdas de la priora la vicaria 
y otras monjas, las salas de consejo, de costura, de música o de labores" ${ }^{\prime \prime}$.

\section{DE FUNDACIONES, ESTATUTOS Y PATRONOS}

Tal como nos anticipa Miura Andrades, las motivaciones fundacionales femeninas aparecen más vinculadas a factores espirituales y de mentalidad que a cualquier otro aspecto de índole económico o social, por ello sugiere la necesidad de "analizar los grupos fundacionales para vislumbrar alguna motivación específica"9.

Por tratarse de los primeros impulsos en el origen de algunas fundaciones dominicas en Córdoba hemos de aludir al fenómeno beato. Este viene caracterizado por la laicidad, la espiritualidad femenina, el retorno a las reglas primitivas, el contacto con el siglo y desarrollo de una religiosidad sin adornos ni reglas consideradas relajadas en un contexto de iniciativa de cooperación, lo que propicia el origen de gran parte de los conventos aquí estudiados a partir del último tercio del siglo $\mathrm{XV}$. De esta naturaleza son los cordobeses de Santa María de Gracia, Santa Catalina de Siena -que posteriormente se refundará en Jesús Crucificado-, Regina Coeli, así como el de Nuestra Señora de la Consolación de La Rambla, todos ellos documentados en el último tercio del cuatrocientos. En el siglo XVI, tienen raíz beata el convento cordobés de Espíritu Santo y el lucentino de Santa Ana ${ }^{10}$.

${ }^{8}$ F. BENÍTEZ, Los demonios en el convento. Sexo y religión en la Nueva España, México, 1995, p. 46.

9 J. M. MIURA ANDRADES, "Las fundaciones dominicas en Andalucía. 1236-1591", en Los Dominicos y el Nuevo Mundo. Actas del I Congreso Internacional, Sevilla, 1988, p. 98.

10 Para el conocimiento del fenómeno beato en Córdoba remitimos a J.M. MIURA ANDRADES, “Las fundaciones de la Orden de Predicadores en el reino de Córdoba (I)", Archivo Dominicano, no 9, 1988, pp. 299-319. Documentación inédita nos señala que Espíritu Santo a fines de 1585 aún continuaba siendo beaterio, mientras que a comienzos de 1598 ya se estaban realizando obras de adecuación de espacios conventuales en las casas emparedadas a la parroquial del Salvador. AGOC, Caja 6.812. CES, Cuentas de la renta que tienen las beatas
Ahora solo cabe preguntarse el motivo por el cual estos beaterios optan por integrarse a la Segunda Orden de Santo Domingo, para lo que Miura Andrades vuelve a ilustrarnos señalando que, de una parte, la alta y baja nobleza vio más factible impulsar sus fundaciones desde los beaterios como paso previo del convento; y de otra, que estas mujeres de nueva espiritualidad prefirieron consejeros dominicos para encauzar su vocación.

Pero, ¿qué tipo de edificios ocuparon los beaterios? La aparición de estos grupos de féminas, en su mayor parte provenientes de los estratos menos favorecidos de la escala social, cuanto menos les obligaba a ocupar inmuebles modestos y alejados de los centros urbanos, generalmente aprovechando lugares tradicionales de culto, peregrinación o romería, donde se conjugan razones religiosas y materiales. En este contexto surgió el beaterio de La Rambla, en una ermita extramuros de la villa, trasladándose años más tarde intramuros por iniciativa del obispo dominico fray Alonso de Burgos (1476-1482) y aprovechando la antigua y ruinosa iglesia de San Bartolomé. De origen bajo-nobiliario es Espíritu Santo, que pasó a fines del siglo XVI de ocupar unas casas en la collación de la catedral a adecuar otras emparedadas a la parroquial del Salvador, sirviéndose de una capilla de ésta como iglesia conventual ${ }^{11}$. Otros beaterios auspiciados por mujeres pertenecientes a la baja nobleza pasaron a ocupar "sus casas principales en el barrio de San Lorenzo" para el caso de Santa María de Gracia, mientras que Regina Coeli "en unas casas donde hacía su morada su fundadora D"a Mencía de los Ríos"12. Distinta tipología arquitectónica tuvo el de Jesús Crucificado,

del Espíritu Santo, 09/12/1585, y Cuentas del convento de monjas de Sancti Spiritus, 23/04/1598.

11 AGOC, Caja 6.812. CES, Cuentas del convento de monjas de Sancti Spiritus, 23/04/1598. Este templo quedó integrado en la clausura en 1782, al fusionarse las parroquias de San Salvador y Santo Domingo de Silos en la antigua iglesia de la Compañía.

12 T. RAMÍREZ DE ARELLANO Y GUTIÉRREZ, Paseos por Córdoba, 6 $6^{\text {a }}$ edición, a cargo de M. Salcedo Hierro, Córdoba, 1985, pp. 59, 200 y 569. 
por haber sido desde 1506 un hospital fundado por los señores de El Carpio, "y a dicho hospital se trasladó el [convento de origen beato] que antes estaba en la collación de Santo Domingo de Silos con título de Santa Catalina de Sena, de dominicas"13.

Por su parte, la alta nobleza participa del proceso fundacional de conventos femeninos dominicos en el Reino de Córdoba desde 1510 con el convento de Madre de Dios de Baena, de manos de los condes de Cabra, linaje de los Fernández de Córdoba, quienes proyectaron un tipo de patronato pleno que no pudo llegar a conformarse para lo que cedió provisionalmente unas "casas propias"14 situadas entre su castillo-palacio y la parroquial de la villa, hasta tanto se edificase $e x$ profeso el convento en otro lugar de la villa. Esta provisionalidad se hizo definitiva tras la muerte en 1525 de don Diego, y haber esperado su hija doña María Carrillo al reparto testamentario del fundador del convento para profesar en él. Ésta, junto los auspicios de su tío don Francisco de Mendoza, obispo de Palencia, impulsó el establecimiento conventual allí donde tuvo lugar su fundación, en lo más alto de la Almedina baenense, gracias a la adquisición paulatina de los inmuebles colindantes de aquellas casas pretendidas como provisionales.

Por su parte, el alto clero también participa del proceso fundacional de la Segunda Orden dominicana, bien favoreciendo fray Alonso de Burgos el traslado y mejor asentamiento de la Consolación dentro de la villa murada de La Rambla, bien contribuyendo con el patronato de la iglesia conventual de Madre de Dios para que sirviera de panteón

\footnotetext{
${ }^{13}$ AFNSR, Cajón 6, Carpeta 4. CJC, Parecer jurídico sobre patronato $y$ dotes, 24/01/1739.

14 "aunque la casa era pequeña por ser de prestado, hasta buscar otro sitio y más largura, se puso la clausura, comenzó el oficio divino, misas y rezado en comunidad y oficinas conforme la pequeñez de la casa y sitios [...] el señor fundador por haber doce monjas y ser la casa estrecha dejó estacase [o fijó] el número hasta agrandar el convento". ACMDB, Caja 1, Libro de hacienda, fol. 279r.
}

particular al obispo de Palencia ${ }^{15}$. No obstante, el gran empuje fundacional por parte del episcopado cordobés se representa con la figura del obispo dominico fray Diego de Mardones (1607-1624), a quien su largo gobierno le permitió promover la fundación en la capital del convento de Corpus Christi y el de Scala Coeli en Castro del Río, con los que quiso contribuir a la expansión del movimiento recoleto o descalzo de la Orden de Predicadores en Córdoba. A las sores del primero se les favoreció el establecerse en la ermita de San Benito y los inmuebles aledaños, cuya compra sufragó Mardones; mientras que a las del segundo influiría para que se situaran inicialmente en el entorno de la castreña ermita de Madre de Dios que les sirvió de iglesia, y tras la reclamación de los derechos sobre la ermita por varias familias hidalgas de la villa, pasaron en 1631 a ubicarse en la calle Ancha de Castro ${ }^{16}$.

También el bajo clero contribuye a la fundación conventual dominica, mediante el espontáneo enriquecimiento de un pobre presbítero que le permitió dotar y fundar el convento de Santa Ana. Si bien, el profesor Miura infiere en esta conversión de beaterio a convento unos motivos no tan milagrosos, como cabría suponer en una localidad foco de alumbrados ${ }^{17}$.

Un último grupo fundacional lo componen los particulares. Es el caso de las dos hijas del regidor de Cabra, doña Francisca y doña María Merino "de estado honesto y vecinas de la villa", quienes con su herencia consiguieron dotar los siete mil ducados necesarios para fundar el egabrense convento de San Martín y Llagas de Cristo, aprove-

15 "que mi cuerpo sea sepultado en la iglesia del monasterio de Madre de Dios de la orden de Santo Domingo de monjas de la villa de Baena, en la capilla mayor de la dicha iglesia y monasterio". ACMDB, Caja 3. Testamento del obispo de Palencia, 17/01/1536, fol. 13r.

${ }^{16}$ B. SÁNCHEZ DE FERIA, Vida de la Venerable madre sor Juana María de San Francisco, Córdoba, 1774, pp. 3745.

${ }^{17} \mathrm{~J}$. M. MIURA ANDRADES, "Las fundaciones de la Orden...", p. 335 
chando las dependencias y la maltrecha ermita del mismo nombre.

Visto lo cual, del grueso de nuestra muestra se evidencia, cuanto menos, la provisionalidad en las estructuras de habitabilidad que desde un primer momento acogieron las comunidades dominicas cordobesas. Unas, ocupando centros religiosos populares y sus dependencias anexas, lo que hace suponer angostura $\mathrm{y}$, sobre todo, precariedad en sus materiales. Otras, estableciéndose en unos inmuebles con estructura doméstica necesitados de adaptación y dotación de espacios adecuados a los requerimientos de la vida religiosa en comunidad. Por tanto, es preciso comprobar el grado de compromiso que son capaces de mantener los patronos en la conformación de la máquina conventual a lo largo del tiempo, ponderar la predilección de la iglesia como aparato escenográfico y político frente al resto de la clausura, saber quién soporta la compra de inmuebles aledaños y quién acomete las reformas. Unos avatares de los que nos da noticia la documentación manejada y desde los cuales desarrollaremos buena parte de nuestros objetivos.

Disponemos de escasos estatutos fundacionales y escrituras de patronato, lo que sin duda dificulta que podamos establecer el grado de implicación de los entes fundadores para con el edificio; empero, de los que sí disponemos, unidos a otras informaciones indirectas, comprobamos cómo estas estipulaciones normativas que atienden a la conformación arquitectónica de la fundación tienen, cuando menos, una observancia poco rigurosa. Este extremo se contrasta con la documentación manejada, señalándonos que es la propia comunidad quien afronta en gran parte o por entero la construcción, adecuación y reforma tanto de la iglesia como del claustro ${ }^{18}$. Esta situación se hace aún más

${ }^{18}$ Sobre los derechos y obligaciones del patronato nos da noticia AGOC, Caja 6.803, Documento 10. CSMLL, Testimonio, 30/11/1775: “según derecho y expresa ley real de partida el patronato se adquiere por tres cosas, la primera por el suelo que se da a la iglesia, patente cuando el patronato es de tipo litúrgico, que radica en la dotación económica para la fundación conventual a cambio de recibir el fundador un servicio religioso a perpetuidad y nombrando como patrona a la priora ${ }^{19}$.

Hemos tenido oportunidad de exponer en otro lugar el proceso fundacional y conformación del convento de Madre de Dios, y comprobar cómo pasó de la provisionalidad del asentamiento y la intención de labrar "casa y monasterio principal", al establecimiento definitivo en ellas y la adición de los inmuebles colindantes. Este hecho propició que al poco se absorbiera el beaterio emparedado a la parroquial, permitiendo constituir en lo más alto del barrio de la Almedina de Baena una estructura única que funcionaba como centro de poder -político, social y religioso- conectando por medio de corredores y pasadizos el castillo-palacio de los condes de Cabra, el convento y la iglesia de Santa María $^{20}$. Hasta mediados del siglo XVII el patrocinio de la Casa de Cabra-Sessa-Baena fue constante en Madre de Dios, habida cuenta la implicación directa que la familia ostentó en los órganos de gobierno conventual, y a partir de entonces el patronazgo iría disipándose con el correr de los tiempos ${ }^{21}$.

la segunda porque se le dé hacienda y la tercera porque se le dé heredamiento que se dice dote."

19 "Primeramente corresponde a este convento de Jesús María de Scala Coeli el vínculo patronato que fundó y constituyó el licenciado D. Martín de Osuna y Rus, presbítero fundador de dicho convento, declarando en el citado patronato como patrona a la priora que era y fuere para siempre en el dicho convento". AGOC, Caja 6.773. CJMSC, Estado del convento, 08/01/1877.

${ }^{20}$ F. M. CARMONA CARMONA, "Fray Juan de los Ángeles, compilador de los estatutos y letras apostólicas del Convento Madre de Dios de Baena (Córdoba)", Archivo Dominicano, no 39, Salamanca, 2018 [en prensa].

21 "Este convento no es fundado bajo cuidado de patronato ninguno, ni se ha oído decir nada, tan solo hay escrito en el protocolo del dicho convento que lo fundó el Duque de Sessa [...] y así es que los señores herederos del dicho señor duque fundador no hacen caso de este convento, conservando solamente la memoria de ser fundador de mencionado convento [...] ni consta por antecedente alguno que el referido duque 

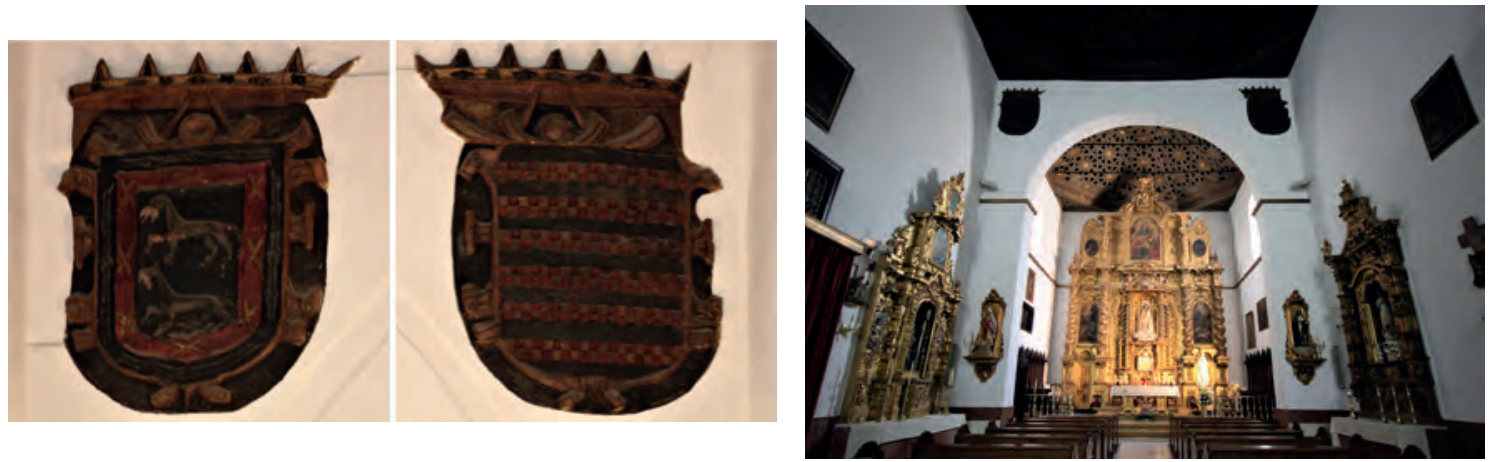

- Fig. 2. Blasones de los marqueses de El Carpio y vista de la capilla mayor de la iglesia del convento Jesús Crucificado (hoy residencia de ancianos San Rafael). Fotos del autor.

Por contra, la Casa de El Carpio presenta una observancia si cabe más continuada con Jesús Crucificado, como corresponde al tipo de patronato pleno. Hasta la invasión napoleónica, durante sus tres primeros siglos de existencia desarrollan una actividad de vigilancia y control que se observa tanto en el cumplimiento de sus obligaciones patronales como en las contraprestaciones que habrían de recibir por parte de este cenobio. No solo estuvieron atentos a construir y dotar convenientemente la iglesia, coro, capilla mayor y torre campanario con sus campanas, sino también su enfermería como vivo recuerdo del origen hospitalario de la fundación.

Por cuanto "las armas denotan señorío", todos los grupos fundacionales estuvieron atentos a señalar su compromiso con los conventos, o al menos con la capilla mayor de su iglesia, bien por ser fundación suya o bien por haber conseguido su patronazgo. Lo cierto es que el escudo de armas se dispone allí donde es fácilmente visto por los demás para indicar claramente el poder $\mathrm{y}$ respetabilidad de una estirpe ${ }^{22}$. Así lo enten-

ni ninguna otra persona per se o por delegado haya ejercido los derechos del citado patronato". AGOC, Caja 6.804. CMD, Informe sobre la solicitud al Nuncio Apostólico en súplica de autorización para vender algunos objetos del convento, 24/03/1899.

22 Sobre este fenómeno son interesantes las reflexiones de E. SORIA MESA, “La imagen del poder. Un acercamiento a las prácticas de visualización del poder en la España moderna", Historia y Genealogía, no 1, 2011, pp. 5-10. dieron los Fernández de Córdoba colocando por doquier blasones de su linaje en Madre de Dios de Baena, como también lo hicieron los marqueses de El Carpio disponiendo sus armas en el arco toral de la iglesia conventual. (Fig. 2) En el egabrense de San Martín y Llagas hubo controversia sobre el patronazgo conventual y la posibilidad de fijar el escudo de armas en la capilla mayor de su iglesia por un litigante, dictaminándose que para blasonarlas había de "obligarse a las obras y reparos que en el futuro se ofrecieren en la dicha capilla mayor $\mathrm{y}$, de pronto, restituyese al convento el todo o parte de lo gastado" ${ }^{\prime 23}$. Justamente así actuó la comunidad de Espíritu Santo en la capilla comprada a la parroquia emparedada, según se desprende de un apunte de descargo como "gasto en la pintura del escudo que se hizo en dicha capilla poniéndosele las armas de Santo Domingo y el Espíritu Santo en señal de que es del convento" ${ }^{24}$.

\section{ADAPTACIONES, AMPLIACIONES, REFORMAS Y SU FINANCIACIÓN}

Precisamente es en Espíritu Santo donde encontramos el grueso noticioso más importante sobre las adaptaciones de espacios realizadas en su proceso fundacional, por cuanto se hace alarde descriptivo en todos los ítems del destino de cada partida

\footnotetext{
${ }^{23}$ AGOC, Caja 6.803, Documento 10. CSMLL, Memoria, 30/11/1775.
}

${ }^{24}$ AGOC, Caja 6.813. CES, Cuentas de los bienes y rentas. 12/06/1651. 
de gasto. Tras su traslado desde la collación de Santa María, se establecen en unas casas emparedadas a la parroquia de El Salvador, comprándole a ésta la lindera capilla del Espíritu Santo para que sirviera de iglesia conventual, no sin antes litigar durante cinco décadas con los beneficiados de la fábrica de esta parroquial ${ }^{25}$. Desde su establecimiento en 1598 y hasta 1650 se estuvo procediendo a reparos en las casas de clausura, adecuando la capilla de El Salvador para que les sirviera de iglesia y adaptando a ella el coro, además de dotar de ornamentos y ajuar litúrgico a la iglesia ${ }^{26}$. Pero, ¿de dónde procedían las grandes sumas que costó este proceso? Fundamentalmente de la explotación de fincas y rendimientos del capital dotacional, así como también de otras vías igualmente rentables y a las que debemos atender, por cuanto el papel de la mujer vuelve a tener un papel fundamental.

De la documentación archivística consultada podemos extraer una gran diversidad tipológica de entradas de capital para poder acometer el gasto que supone la construcción de la iglesia conventual. Sabido es que su construcción supone el monto más elevado de todo el inmueble conventual por las características intrínsecas de la edificación, lo que obligaba a articular fórmulas de financiación en las que el censo se convierte en la más utilizada. El buen manejo y administración de los caudales conventuales aplicados a este producto financiero permite la obtención de unos sustanciosos beneficios que posibilitan cualquier tipo de empresa edilicia. Así se advierte en el convento de La Rambla, pues se erige desde finales del siglo XVI en verdadera entidad financiera de la localidad, obteniendo jugosas rentas que en gran parte se destinaron a la edificación de su iglesia conventual y más tarde su torre

\footnotetext{
${ }^{25}$ El conflicto se saldó con el pago por parte del convento de 66 reales (r.) de renta perpetua en cada año a la fábrica de la parroquial y obligación de decir sus clérigos cada año cuatro fiestas. AGOC, Ibídem.

${ }^{26}$ AGOC, Caja 6.812. CES, Cuentas del convento de monjas de Sancti Spiritus, 23/04/1598.
}

campanario $^{27}$. De entre los apuntes contables de este cenobio sobresale el dato inédito de su arquitecto, Juan de Ochoa (1554 - 1606) coetáneo y colaborador de Hernán Ruiz III; del mismo modo que por esta vía queda también demostrada su autoría en las trazas de la iglesia conventual de Santa María de Gracia $^{28}$.

Pero la construcción de una iglesia precisa de un apoyo pecuniario considerable, por lo que las comunidades dominicas abrieron las puertas de sus iglesias para atraer cualquier tipo de ayuda a su fábrica, bien mediante el intercambio escatológico que permite el patronazgo y enterramiento en sus capillas laterales ${ }^{29}$, bien buscando limosnas aprovechado cualesquier lazo de parentesco, afinidad o vecindad ${ }^{30}$. (Fig. 3)

${ }^{27}$ Passim AHN, Clero Secular Regular, Libro 3.041.

${ }^{28}$ AHPCO, Clero, Libro 1.064. CNSC, Cuentas, 15881604, el apunte del arquitecto cordobés en 1598; y Libro 1.275. CSMG, Cuentas, 1601-1617, fols. 2r-v.

${ }^{29}$ Sería largo y prolijo enumerar todas las referencias encontradas sobre este mecanismo de financiación, sirva este ejemplo: "Ítem mando que por cuanto el convento y priora de Madre de Dios me han dado un sitio y capilla donde está enterrada mi hermana y un sobrinico mío y no les he dado por ello nada, se le dé 300 ducados (dc.) [...] y que la capilla que me tiene dada se abra por el cuerpo de la iglesia en la cual se haga una reja de hierro a mi costa [...] y para dicha capellanía se dota de un censo de 700 ducados [...] Ítem nombro por patrona a la priora y prioras que la sucediesen $[\ldots]$ Ítem nombro por mi legítimo y universal heredero al Santo Monasterio de Madre de Dios de Baena, así por el mucho amor y devoción que le tengo [...] y sobre todo porque tenga cuidado mi señora la priora y todo el convento de rogar a Dios por mí [...] y sobre todo porque haga merced de darme una sepultura dentro de su coro para que no se olviden de quien tanto las quiso, pues les dejo todo cuanto tengo" AHPCO, Baena, Signatura 89P. Testamento y codicilo de María de Sanabria, fols. 540-552, 19 y 20/05/1606.

30 "Don fray Martín de Mendoza, obispo de Córdoba [...] entre otras obras y bienes que hizo fue tomar la capilla que decimos del Cristo y dotarla y dio ochocientos ducados en oro, de los cuales el convento tomo los cuarenta mil maravedís de ellos por la fábrica y edificio [...] lo demás se echó en renta para las misas" ACMDB, Caja 1, Libro de hacienda, fol. 267r; o bien, la obligación de Jesús Crucificado para con el obispo de Málaga, don García de Haro y Sotomayor, quien ejercía 
También las dotes de profesión sirvieron para financiar las obras en los claustros objeto de estudio, con la consiguiente merma del rendimiento de capital que este aporte supone a las rentas conventuales, por lo que para su aplicación estaba el convento obligado a pedir dispensa del ordinario o provincial de la Orden. En otros casos se acompañó al importe dotal gruesas limosnas para remedio de la comunidad, lo que nos habla de un procedimiento elitista de donde se infiere que la ascendencia y el dinero son las llaves principales que abren las puertas de los conventos en Edad Moderna. Como el caso de doña María Mesa y Ganancia, quien tras enviudar ingresó en Escala Coeli y además de su dote aportó 14.000 ducados para la obra de su iglesia; o los 1.000 ducados que aportó a Jesús Crucificado doña María Mellado "por vía de limosna por entrar en plaza del marqués que dio al convento para gastos de obras"31.

Las celdas fueron objeto de mercantilización entre las comunidades dominicas, encontrando en este mecanismo un medio con el que cargar sus arcas o ampliar con inmuebles vecinos las dimensiones conventuales. Un aspecto que subraya la predilección de los bienes propios y el apego al desarrollo de la vida privada aún dentro de un ámbito comunitario y colaborativo. En concreto, como hemos comprobado con la cita de Fernando Benítez, estos espacios eran auténticas residencias que se habían levantado dentro

en 1596 de administrador del estado de El Carpio [ADA, Caja 81, no 22] por "haber hecho y hace a este convento muchas y muy buenas obras, en especial en haber cubierto como cubrió la iglesia nueva del dicho monasterio [1586] que había mucho tiempo que estaba descubierta" AGOC, Caja 6.809. CJC, Copia de escrituras, 27/09/1796; por su lado Nuestra Señora de la Consolación también fue beneficiada por el alto clero, en concreto una limosna de 100 dc. que recibió en 1601 de su paisano rambleño, don Juan de San Clemente y Torquemada (1534-1602), arzobispo de Santiago de Compostela. AHPCO, Clero, Libro 1.064. CNSC, Cuentas, 1588-1604.

31 AGOC, Caja 6.773. CJMSC, Comunicaciones, 10/02/1647; AFNSR, Cajón 10, Libro 1. CJC, Libro de profesiones, fol. 64r, 09/09/1677.

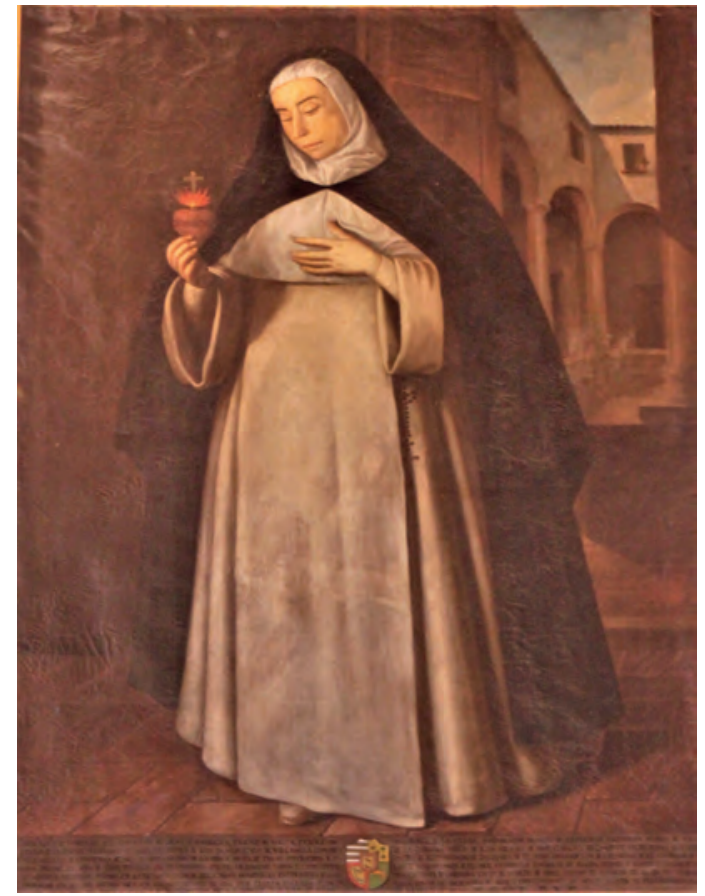

- Fig. 3. Anónimo. Retrato post mortem de sor María Victoria del Corazón de Jesús Cabrera, priora de Corpus Christi. Segundo tercio siglo XIX. Iglesia de La Magdalena (Córdoba). Foto del autor.

o añadido al convento, y altamente demandadas por aquellas sores con elevado poder adquisitivo. Tras el fallecimiento de la monja propietaria el convento asume la propiedad, a menos que ésta haya establecido pase a dominio de otra religiosa que por lo general le ha servido de ayuda en la ancianidad o enfermedad. Como tal título de propiedad "las obras forales o exteriores las costea el convento, sean mayores o menores, y por lo que toca al cuerpo de celda que habitan las religiosas, las costean ellas aunque sean obras mayores"32. Hubo celdas de dominio particular de sagas familiares que heredan el usufructo de la misma hasta el fallecimiento de la última integrante, habiendo casos en los que incluso se subarriendan estas estancias a otras religiosas aún sin ser parientas ${ }^{33}$.

\footnotetext{
${ }^{32}$ AGOC, Caja 7.420, Documento 17. CES, Súplica de la priora al obispo, 13/05/1808.

33 “Propuso la priora que por [la proximidad de la] muerte de sor Andrea de Guzmán, su celda quedaría vacía, la cual era necesario vender para su funeral y deudas y doña Mariana de Cárdenas quiere pagarle
} 
Cuando fallece la propietaria de una de estas casas-celda la comunidad se hace cargo de administrar convenientemente el inmueble, generalmente revertiendo la situación, y tras su reventa se sufragan los gastos de sepelio y misas de la propietaria y el resto de ganancia entra en las arcas conventuales ${ }^{34}$.

Los gastos en reformas y conservación del monasterio son numerosos, documentándose prolijamente en los libros de cargo y data, si bien se refieren a obras menores o, cuanto menos, así se desprende de las expresiones empleadas en los apuntes y en el valor de las mismas. Nos sirven además estos apuntes para establecer fechas en este proceso de adaptación; como la dote necesaria para pagar lo adeudado en Corpus Christi de "la obra que ha sido mucha cosa, así se le ha dado forma de convento que no la tenía, y un refectorio que aún no lo tenía" ${ }^{35}$. Pese a todo, consideramos esencial este ejercicio de

para que la goce su hija sor María de Godoy y otras tres hijas que tiene y han de ser religiosas en este convento". AFNSR, Cajón 4, Libro 2. CJC, Libro de consultas, 15/05/1675.

${ }^{34} \mathrm{Si}$ bien esta es una generalidad advertida en toda la muestra, por contener un verdadero corpus casuístico de la mercantilización de las celdas conventuales, escogemos lo referido en AHPCO, Clero, Libro 296. CES, Libro de entrada de arca, fols. 98r-99v: "Por muerte de doña Jacinta Mardones [1663] vacó la celda que era suya, la cual pidió al convento que la gozase por sus días doña Antonia Almoguera por haberle asistido en su enfermedad y haberle ayudado a algunas obras en la dicha celda... / Por muerte de doña Antonia Almoguera [1674], heredó dicha celda el convento, la cual vendió en 2.000 r. a doña María de Montoro, los cuales entraron en arca del depósito [En glosa: se apreció en 1.500 reales y los prelados lo subieron a 2.000] / El mismo año se vendió otra celda por 1.750 r. / En 1675 se recibieron 150 r. que aún debía una religiosa por una celda / En 1679 vendió una celda [antes de morir] doña Ana del Pino para su entierro y hacer bien por su alma y pagar algunas deudas. Le tocó al convento de expolio $350 \mathrm{r}$. los cuales entraron en el arca / En el año 1732 se vendió la celda de la madre doña Francisca de Robles a doña María Castril en 1.350 r. de los cuales se entraron en el arca de capitales 200 r. y se repartieron a las religiosas $300 \mathrm{r}$. y de lo restante se hizo un cáliz para el convento y se dijeron misas por su alma".

35 AHPV, Legajo 79, expediente 7. CCC, Fes de algunas madres primitivas, fol. 42r, 21/07/1662. mantenimiento patrimonial, sobre todo en los trabajos de conservación de las cubiertas, pues en ello redunda gran parte de la estabilidad estructural de los edificios. De igual modo, se contabilizan los gastos por reparos de los destrozos provocados por el terremoto de Lisboa de primero de noviembre de 1755, lo que nos ofrece una idea de las consecuencias que provocó el sismo en la capital cordobesa $^{36}$. Otro motivo de aplicación de grandes dispendios para acometer reformas tuvo lugar con la invasión napoleónica y la ocupación de los conventos dominicos cordobeses como acuartelamiento de la soldadesca. En concreto, Santa María de Gracia tras su abandono por los franceses, tuvieron que ser reedificadas numerosas dependencias, lo que obligó a malvender objetos litúrgicos de plata y numerosos inmuebles diseminados por la capital ${ }^{37}$. A partir de entonces, la situación fue agravándose progresivamente por las exclaustraciones y los procesos desamortizadores que dejaron a los conventos sin rentas, sin posesiones y mal subsidiados. Comienzan así a documentarse una larga serie de peticiones para acometer reparos urgentes en los inmuebles conventuales, que conllevará como vía de solución la venta del patrimonio mueble como remedio a la situación de ruina que muchos claustros soportaron. Pero ese fenómeno es motivo de estudio detenido.

\section{EL TESORO ARTÍSTICO MUEBLE AL SERVICIO DE SU CONVENTO}

La documentación consultada nos señala que desde comienzos del siglo XVIII las economías de las comunidades estudiadas vienen resintiéndose por diversos contratiempos. En buena parte, por la paulatina desvinculación de los grupos fundacionales en el mantenimiento de sus obligaciones, lo que provoca no pocas peticiones a los maes-

${ }^{36}$ AHPCO, Clero. Libro 1.277. CSMG, Cuentas de los bienes y rentas del convento, 20/03/1792; AFNSR, Cajón 8, Libro 3. CRC, Libro de capitales, fol. 40v.

${ }^{37}$ AHPCO, Clero. Libro 759, CSMG, Cuentas, 18111828. 
tros provinciales y obispos para la suspensión del todo o parte de las cargas de misas contraídas a perpetuidad por el convento para con sus benefactores. Con esto, se intenta aliviar algo los enormes gastos que esta partida implica; como el ajuste a una tercera parte de las misas, entre cantadas y rezadas, que Jesús Crucificado tenía obligación de celebrar "por su fundación y otros legados píos"38. Otro problema que evidencian los archivos conventuales son los largos periodos de sequía y numerosas plagas que asolan los campos propiedad de nuestras comunidades $y$, por consiguiente, la merma de las rentas con las que se atienden gran parte de las construcciones y reparos en sus edificios. La situación es tal, que a fines de esta centuria se dirigen peticiones a los patronos para que dejen de nombrar religiosas "a título de patronato", y que las que se nombren, entren con dote suficiente para su sustento y aporten limosna "por ser todo de fábrica muy antigua" y se puedan desempeñar reparos ${ }^{39}$. A su vez, se documentan numerosas ventas de inmuebles para desahogo de las arcas conventuales, que unido al capital obtenido de la redención de censos se impone en la "Real Caja" ${ }^{\prime \prime}$, y que a la postre repercutirá en terribles consecuencias.

Pese a esta situación, la entrada de las tropas francesas en la capital cordobesa sería el detonante para la progresiva desaparición de los claustros aquí estudiados, dándoles el definitivo golpe de gracia los procesos desamortizadores y crisis políticas que jalonaron todo el siglo XIX. En este sentido, un memorial de 1861 redactado por una religiosa de Jesús Crucificado nos ayuda a desentrañar los vericuetos atravesados por parte de los claustros cordobeses, que ocasionaron la pauperización de las comunidades religiosas, la merma de su población, la remoción

${ }^{38}$ AFNSR, Cajón 9, Libro 3. CJC, Libro de obligación de misas. 1763, fol. 3r-v.

${ }^{39}$ AFNSR, Cajón 2, carpeta 2. CJC, Cartas útiles del patrón, 22/11/1787.

${ }^{40}$ AFNSR, Cajón 2, carpeta 2. CSMG, Cartas de recibo, 02/05/1807. de gran parte de sus integrantes $y$, por consiguiente el cierre, cambio de uso y pérdida de buena parte de las estructuras edilicias que las alojaron durante siglos:

"Habiendo venido las tropas francesas a esta ciudad el año de 1808 fue suprimido el convento de Regina, religiosas dominicas de esta ciudad, viniéndose a éste [...] En el año de once, con motivo de haber vuelto a entrar en esta ciudad los franceses fueron suprimidos algunos conventos y tocándole también a el de Santa María de Gracia pidieron las trajesen reunidas a éste de Jesús Crucificado donde permanecieron cerca de tres años [...] Habiéndose puesto en España la Constitución fueron suprimidos los conventos de religiosos y religiosas, muchos de ellos continuando las reuniones conforme iba faltando el número de doce. Todas las rentas fueron recogidas por el Crédito Público, posesiones de censos y pertenencias que poseían los conventos, señalando a cada religiosa una peseta diaria para su manutención y 180 reales para cada convento cada mes para gastos de enfermería; y pasado tiempo señalaron 307 reales cada mes para gastos de culto. Día 10 de agosto de 1836, vinieron reunidas [once madres] por haber suprimido sus conventos del Espíritu Santo y Regina de esta ciudad, que al tiempo de la supresión de su convento fueron al de Santa María de Gracia, y no hallándose gustosas fueron trasladadas a éste. Día 24 de junio de 1838, no pudiéndose sostener la vida común con motivo de no poder la Nación tener corrientes las pagas de los cuatro reales señalados a cada religiosa, por lo que se estaba sosteniendo la comunidad algunas veces con limosnas, que no se solían encontrar por hallarse todos los conventos en la misma situación, se propuso la vida particular y concediéndola ese mismo día el señor Gobernador Eclesiástico [...] Día 20 de agosto de 1838 vinieron reunidas a este convento [cuatro madres] del convento de Consolación de La Rambla, por haber quedado tan pocas religiosas que no pudieron seguir en él y quedó suprimido. Todos los conventos se iban apurando por haberse quitado por el Gobierno las licencias de hábitos y 
profesión, por lo que todas las novicias que les cogió sin profesar se quedaron sin poder ser religiosas, como sucedió en este convento a varias novicias [...] Pasó el Gobernador Político a ver el convento con otras personas que le acompañaban, como lo hizo en todos los demás conventos antes de suprimirlos, para ver los que habían de quedar y los que habían de suprimir" ${ }^{41}$.

En este estado de cosas, es fácil entrever las complicadas vicisitudes de todo tipo que tuvieron que atravesar las dominicas cordobesas. Los subsidios pronto demostraron ser ineficaces e insuficientes para el mantenimiento mínimo personal de las religiosas y sus comunidades. Los impagos y la tardanza en su cobro abocaron a que las comunidades arbitraran soluciones para hacer frente a su calamitosa situación económica; por tanto, ¿qué mejor que la venta de los objetos de valor disponibles? Lo más habitual fue desprenderse de la plata, puesto que era habitual disponer de varias piezas de vasos sagrados y ajuar litúrgico, y tratarse de un material fácilmente convertible en moneda corriente con tan solo proceder a su pesado. El monto resultante de estas prácticas permitió, de un lado, aplicarlo al sostenimiento de las necesidades básicas de las religiosas; y de otro, poder mantener las estructuras edilicias de los conventos que aún estaban activos, para -a la vista de los escrúpulos que suponía morar en convento distinto al de su orden- evitar en la medida de lo posible la remoción y dispersión de su población. Así, el mantenimiento de las estructuras arquitectónicas conventuales se convirtió en objetivo primordial durante estos difíciles años, pues disponían de los recaudos necesarios

${ }^{41}$ AFNSR, Cajón 5, carpeta 3. CJC, Memorial, 4 fols. [f. 2 disperso en Cajón 5, Libro 1] y AGOC, Caja 6.810. CJC, Relación de religiosas, 03/03/1837, nos indican no se tuvo cuidado en respetar la orden o filiación de las comunidades reunidas, pues Jesús Crucificado fue convento de reunión tanto de religiosas franciscanas, clarisas, bernardas o benitas procedentes de otros conventos cordobeses suprimidos. Del mismo modo que se documentan la reunión de dominicas egabrenses y lucentinas en los conventos de agustinas y carmelitas de sus respectivas localidades. para ello en los anaqueles, vitrinas y cajoneras de sus sacristías.

Las informaciones que se desprenden de los fondos documentales conventuales nos indican que las alhajas y piezas de plata pertenecientes al ajuar litúrgico fueron largamente demandadas tanto por las autoridades civiles como religiosas, pero la obediencia de su entrega se presume cuanto menos poco rigurosa ${ }^{42}$. Se nos antoja que las comunidades eran conocedoras o habían sido advertidas del gran recurso económico que atesoraban intramuros, por lo que ante las exigencias de participación a los gastos nacionales pudieron hacer desaparecer provisionalmente gran parte de estos efectos ${ }^{43}$, a la vista de las experiencias vividas durante la invasión napoleónica ${ }^{44} \mathrm{y}$ del gran número de objetos de plata que se documentan en los inventarios de bienes realizados durante el siglo XIX y comienzos del XX.

A partir de entonces, los fondos que custodian tanto el archivo diocesano cordobés como los conventuales, aportan una sólida apoyatura documental que nos permite evidenciar cómo los conventos dominicos

${ }^{42}$ AFNSR, Cajón 2, carpeta 6. Instrucción que S.M. se ha dignado aprobar para la aplicación a los gastos urgentes del Estado, de las alhajas y plata de las iglesias que no son absolutamente necesarias para el culto, dado en el Real Alcázar de Sevilla por don Juan de Trevilla, obispo de Córdoba, 08/04/1809. Las reservas de la población cordobesa por la filiación afrancesada de su obispo no haría sino inclinar a las comunidades a la inobservancia de sus requerimientos.

${ }^{43}$ Por ejemplo, la solicitud dirigida por la priora de Scala Coeli al Obispo de Córdoba para interceder en la devolución de unos bienes: "sin conocimiento del prelado entregué al sr. Conde de la Estrella, en los días que fuimos despojadas de nuestros bienes y alhajas, las mejores de esta comunidad, pero espero que VI en esta parte sea indulgente conmigo. Me disculpa mi buena intención lo apurado de las circunstancias azarosas que atravesábamos y el rango de la persona a quien hice la entrega". AGOC, Caja 6.773. CJMSC, Asuntos Varios, $11 / 02 / 1844$.

${ }^{44}$ AFNSR, Cajón 3, Libro 3. CSMG, Cuaderno de gasto de contadora, fol. $23 \mathrm{r}$ "gastos extraordinarios: en deshacer la plata de la sacristía para la paga del subsidio, 153 r." entre otros ítems relevantes. 
vienen considerando reserva de capital todos aquellos bienes en forma de alhajas y objetos de plata u oro. Pues, a la vista de la situación acaecida y ante las necesidades de capital efectivo, comienzan las comunidades a vender objetos de valor para así poder afrontar los gastos más perentorios ${ }^{45}$. Unas veces, previa solicitud al obispado cordobés, quien generalmente accedía al requerimiento, pero otras muchas sin mediar comunicación ni aprobación. Por una y otra vía se perdieron las viejas casullas, capas pluviales y dalmáticas ricamente bordadas de plata y oro con engarces de pedrería ${ }^{46}, \mathrm{y}$ acabándose éstos no hubo más remedio que sacrificar esculturas, pinturas, ornamentos, azulejos o cualquier cosa que aliviara la situación ${ }^{47}$. (Fig. 4) Todo recurso se consideraba poco con tal de socorrer a las comunidades y evitar el cierre y traslado de convento.

45 “[por obras realizadas en el convento] se está debiendo a dos acreedores la cantidad de 50.446 r. y no teniendo medios para pagarlos, [se propone] vendiese alguna plata para pagar dichas deudas por no haber otro arbitrio con las muchas contribuciones que han cargado al convento en estos años, por cuyo motivo han venido estos atrasos" AFNSR, Cajón 4, Libro 2. CJC, Libro de consultas, 16/03/1820. Se convino vender el frontal de plata del altar mayor y pedir licencia al obispo; éste decretó conceder licencia para su venta. No obstante, la priora propuso nuevamente "que no habiendo sido suficiente el valor del frontal para pagar las deudas que les propuso en la consulta anterior, que era necesario vender más plata por lo que se convinieron en que se vendieran la cruz alta y los ciriales, el atril y dos azafates pequeños", concediéndoles de nuevo licencia por lo justificado de sus motivos.

46 “Se quemó el terno de tela viejo y salieron 41 onza de plata, las que pagaron a $18 \mathrm{r}$. la onza que importó por mayor 738 r." AFNSR, Cajón 4, carpeta 3. CJC, Libro de cuentas, 03/02/1821.

47 “[01/02/1841] Recibimos por el viril 1.263 r. [01/04/1842] Recibimos de seis laminas que se vendieron 1.000 r., más de dos lienzos pequeños de la capilla del Señor del Perdón 38 r., más de otras tres láminas del coro recibimos $160 \mathrm{r}$., de cinco ornamentos viejos que se han vendido recibimos 120 r., de un frontal blanco y la sobremesa 99 r., de un ornamento negro con la guarnición de fleco y otro blanco de tela recibimos 204 r. [27/06/1843] Recibimos de las madres depositarias quinientos reales de la plata vendida". AFNSR, Cajón 1, Libro 3. CSMG, Libro de cuentas.
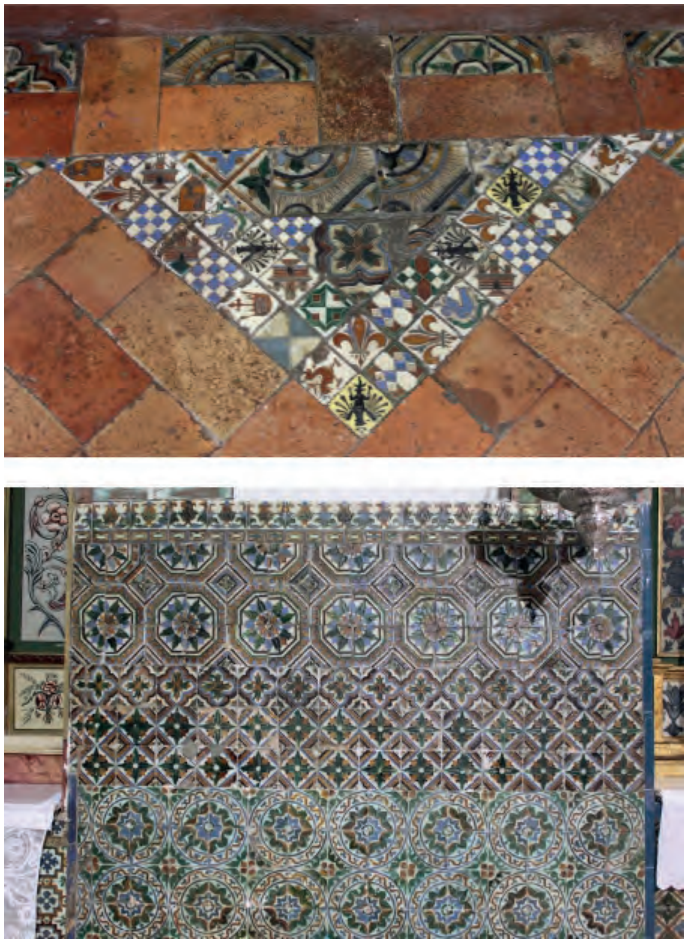

- Figura 4.- Sendos ejemplos de azulejería parietal y en el pavimento del convento Madre de Dios de Baena. Fotos del autor.

“Día 28 de mayo de 1856, con motivo de amenazar ruina el tejado de la iglesia, la madre sor María Negrete viendo que no tenía el convento para costear una obra de tanto costo ni el crédito público la costeaba, y que sería motivo para que el convento se cerrase pasando la comunidad a otro convento, salió dicha religiosa a costear la obra no solo de la iglesia sino otras muchas que continuamente costeaba a fin de sostener el convento" ${ }^{\prime 4}$.

Las medidas desamortizadoras de Mendizábal alteraron profundamente el conjunto conventual dominico cordobés, desarmando gravemente el entramado de vida consagrada al clausurar los conventos de La Rambla, Cabra, Lucena y el de Regina en la capital. En 1868, la Gloriosa acabó con los desvelos contemplativos de la comunidad de Jesús Crucificado. Pero las cosas no fueron a mejor. Los subsidios continuaban resultando escasos o sencillamente no llegaban, las limosnas procedentes de los vecinos no siempre eran suficientes para costear las

\footnotetext{
${ }^{48}$ AFNSR, Cajón 5, Carpeta 3. CJC, Memorial, fol. 3v.
} 
obras necesarias ${ }^{49}$, encontrándonos ante una situación que no favorecía en absoluto las devociones y que estaba abocada irremisiblemente a la desaparición de los conventos. Motivos suficientes para que las súplicas de ayuda a la manutención de las comunidades y los reparos de estructuras edilicias se apilaran en los despachos del obispado cordobés. En este contexto, la priora de Madre de Dios dirige en 1869 una solicitud al obispo para que se permita vender alhajas e imágenes del ajuar particular de las religiosas para solventar en parte la situación de riesgo que amenazan las estructuras conventuales ${ }^{50}$. Los 4.265 reales producto de la venta de estas alhajas se aplicaron a las obras de más necesidad, pero resultaron insuficientes para el mantenimiento que demandaba el monasterio desde hacía mucho tiempo. Esta misma situación de carestía y necesidad es aplicable a los otros tres conventos activos, evidenciando la documentación en todos ellos el sacrificio realizado del patrimonio artístico mueble en favor del mantenimiento del arquitectónico. Una situación acuciada por la necesidad que provocó no pocos abusos y engaños por intermediarios, marchantes y anticuarios sin escrúpulos.

\footnotetext{
49 "En diferentes ocasiones ha solicitado la obra para esta iglesia y monasterio que contando más de tres siglos de existencia [...] algunas personas caritativas costearon a sus expensas el año anterior la que necesitaba la capilla mayor de la iglesia y dormitorio interior que se llovía, pero agotado este recurso [...] suplican se digne conseguir del Gobierno de Su Majestad el que franquee medios para estos indispensables reparos". AGOC, Caja 6.804. CMD, Obras de reparación, 15/09/1857.

50 "exploradas acerca del destino que quería se le diese a las alhajas, siendo la respuesta que todo cuanto tenían y conservaban lo destinaban para ayudar a la obra de su convento"; a lo que el Obispado contesta: "venimos en autorizar a V. para que disponga se proceda a la reparación del convento en la inteligencia que no contando con otros recursos que el producto de las alhajas que expresa el inventario". AGOC, Caja 6.805. CMD, Comunicaciones, 09/06/1869.
}

\section{A MODO DE CONCLUSIÓN ABIER-} TA

Solo resta concluir que Scala Coeli de Castro del Río fue incendiado en 1936, obligando a su comunidad a reunirse en Corpus Christi. Así, de los diez cenobios fundados en Edad Moderna, tan solo continúan manteniendo hoy su función Madre de Dios de Baena y Santa María de Gracia -si bien éste último en un nuevo emplazamiento tras la reunión de su antigua comunidad con la de Corpus Christi-. La iglesia y diversas dependencias de Jesús Crucificado se conservan gracias a su reconversión en asilo tras innumerables vicisitudes ${ }^{51}$. El resto de conventos han tenido toda suerte de destinos. De algunos solo se conservan determinadas estructuras por ser considerados hitos fundamentales del paisaje de la localidad, como la espadaña de Scala Coeli de Castro del Río o la formidable torre campanario de Nuestra Señora de la Consolación de La Rambla. El convento de Santa Ana de Lucena se derruyó, salvándose tan solo la portada de acceso a la iglesia conventual que se trasladó al $\mathrm{Mu}$ seo Arqueológico Provincial. Corpus Christi pasó recientemente a convertirse en sede de la Fundación Antonio Gala para Jóvenes Creadores tras una integral restauración. La iglesia y claustro de Regina Coeli se encuentran desde hace décadas en fase de conservación y pendiente de restauración para dependencias culturales municipales. (Fig. 5) Lo que era el antiguo convento de Santa María de Gracia es hoy una plaza, donde solo queda la estructura pétrea de la portada de su iglesia conventual como huella de su ubicación y sin indicación alguna que informe de su antigua función. No queda nada del convento del Espíritu Santo, que fue fruto de especulación en la reordenación urbanística acometida en Córdoba desde mediados del siglo XIX; y en el solar que ocupara el con-

\footnotetext{
51 Tras la exclaustración de las religiosas se destinó a Cuartel de Infantería, siendo muy pretendido por distintos organismos para establecer en él sus dependencias. AGOC, Caja 6.808, Documento 14. CJC, Asuntos Varios, 26/11/1880.
} 
vento de San Martín y Llagas se levantó el edificio del ayuntamiento de Cabra.

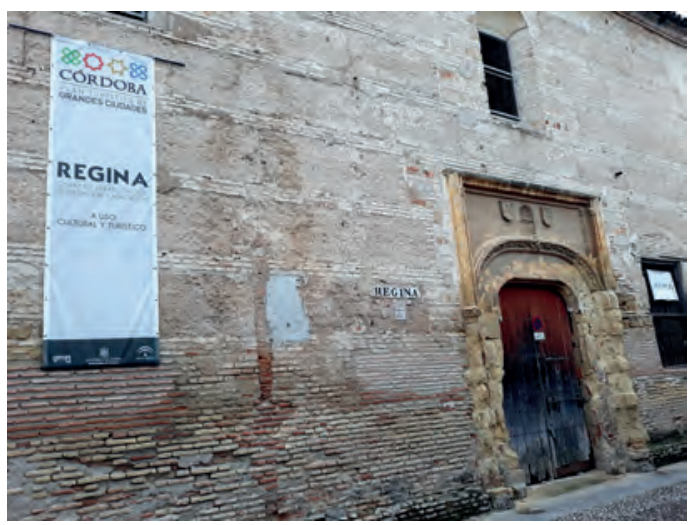

- Figura 5.- Imagen del convento Regina Coeli, que se encuentra a la espera de adecuación para uso cultural. Foto del autor.

Obligado es decir que en la actualidad se han invertido los esfuerzos patrimoniales, pues, en tanto desaparecen otros conventos de dominicas, aumenta el patrimonio artístico mueble en Madre de Dios de Baena y Santa María de Gracia. Ello es debido a que la falta de vocaciones, el aumento de la esperanza de vida de las religiosas y factores económicos obligan al cierre de los conventos y la consiguiente reunión de estas comunidades en otras. Por tanto, se viene atesorando paulatinamente un patrimonio artístico, bibliográfico y documental procedente de estos claustros; lo que viene a dificultar la adscripción a un claustro determinadas piezas si previamente no se somete a una labor de catalogación e inventario previo. Algo que ha venido siendo habitual.

\section{BIBLIOGRAFÍA}

ARANDA DONCEL, J., La ermita de Madre de Dios de Castro del Río. Estudio Histórico Artístico, Córdoba, 1992.

ARANDA DONCEL, J., "Trayectoria histórica del monasterio del Corpus", en A. VILLAR MOVELLÁN (dir.), El Convento de Dominicas del Corpus Christi de Córdoba (1609-1992), Córdoba, 1997, pp. 17-78.
ARANDA DONCEL, J., "Un confesor regio al frente de la diócesis de Córdoba: el dominico Fray Diego de Mardones (15281624)", Archivo Dominicano, no 36, 2015, pp. 61-135.

ATIENZA LÓPEZ, Á., Tiempo de conventos. Una historia social de las fundaciones en la España Moderna, Madrid, 2008.

ATIENZA LÓPEZ, Á., "El mundo de las monjas y de los claustros femeninos en la Edad Moderna. Perspectivas recientes y algunos retos", en E. SERRANO MARTÍN (Coord), De la Tierra al Cielo. Líneas recientes de investigación en Historia Moderna, 2012, Vol. 1, pp. 89-108.

CARMONA CARMONA, F. M., "Parámetros nobiliarios y política de prestigio en el convento Madre de Dios de Baena (Córdoba)", en Hispania Sacra [en prensa].

CARMONA CARMONA, F. M., "Fray Juan de los Ángeles, compilador de los estatutos y letras apostólicas del Convento Madre de Dios de Baena (Córdoba)", Archivo Dominicano, no 39, Salamanca, 2018.

BENÍTEZ, F., Los demonios en el convento. Sexo y religión en la Nueva España, México, 1995.

CERRATOS MATEOS, F., Monasterios femeninos de Córdoba: patrimonio, rentas y gestión económica a finales del Antiguo Régimen, Córdoba, 2000.

DOBADO FERNÁNDEZ, J. e YLLESCAS ORTÍZ, M., Córdoba ciudad conventual, Córdoba, 2014.

GÓMEZ NAVARRO, S., "Patrimonio monástico y conventual en la España Moderna: formas y fuentes de formación y consolidación", en M. I. VIFORCOS MARINAS y R. LORETO LÓPEZ (coords.), Historias compartidas, religiosidad y reclusión femenina en España, Portugal y América, siglos XVI-XIX, León, 2007, pp. 435-465.

GRAÑA CID, M. M., "Poder nobiliario y monacato femenino en el tránsito a la Edad Moderna (Córdoba, 1495-1550)", 
Cuadernos de Historia Moderna, vol. 37, 2012, pp. 43-72.

GRAÑA CID, M. M., Religiosas y Ciudades. La espiritualidad femenina en la construcción sociopolítica urbana bajomedieval (Córdoba, siglos XIII-XVI), Córdoba, 2010.

HERRERA MESA, P. P., “El episcopado cordobés de Pedro Antonio de Trevilla en el primer tercio del siglo XIX (1805-1832)", Boletín de la Real Academia de Córdoba, $\mathrm{n}^{\mathrm{o}}$ 162, 2013, pp. 277-293.

JORDANO BARBUDO, M. Á., El Mudéjar en Córdoba, Córdoba, 2002.

MIURA ANDRADES, J. M., "Las fundaciones dominicas en Andalucía. 1236-1591", en Los Dominicos y el Nuevo Mundo. Actas del I Congreso Internacional, Sevilla, 1988.

MIURA ANDRADES, J. M., "Las fundaciones de la Orden de Predicadores en el reino de Córdoba (I)", Archivo Dominicano, no 9, 1988, pp. 267-372.

MIURA ANDRADES, J. M., "Beatas y beaterios andaluces en la Baja Edad Media: Su vinculación con la Orden de Predicadores", en E. CABRERA MUÑOZ (coord.), Andalucía entre Oriente y Occidente, (12361492), Córdoba, 1988.

MIURA ANDRADES, J. M., "Milagros, beatas y fundaciones de conventos. Lo milagroso en las fundaciones dominicas desde inicios del siglo $X V$ a finales del siglo XVI", en ÁLVAREZ, BUXÓ y RODRÍ-
GUEZ (coords.), La Religiosidad Popular, Barcelona, 2003, Vol. II, pp. 443-460.

MIURA ANDRADES, J. M., “Las fundaciones de la Orden de Predicadores en el reino de Córdoba (II)", Archivo Dominicano, no 10, 1989, pp. 231-297.

OLMEDO SÁNCHEZ, Y. V., "Bastiones de oración: arquitectura y espacios monacales femeninos en el Reino de Córdoba durante la Edad Moderna", Tiempos Modernos: Revista Electrónica de Historia Moderna, no 25, 2012, 40 pp.

OLMEDO SÁNCHEZ, Y. V., "De la ciudad conventual a la ciudad burguesa: las órdenes religiosas en la evolución urbana de Córdoba", Hispania Sacra, no 129, 2012, pp. 29-66.

RAMÍREZ DE ARELLANO Y GUTIÉRREZ, T., Paseos por Córdoba, 6⿳a edición, a cargo de M. SALCEDO HIERRO, Córdoba, 1985.

SÁNCHEZ DE FERIA, B., Vida de la Venerable madre sor Juana María de San Francisco. Córdoba, 1774.

SORIA MESA, E., "La imagen del poder. Un acercamiento a las prácticas de visualización del poder en la España moderna", Historia y Genealogía, no 1, 2011, pp. 5-10.

VILLAR MOVELLÁN, A. (dir.), El Convento de Dominicas del Corpus Christi de Córdoba (1609-1992), Córdoba, 1997. 